\title{
Baa! Humbug! Christmas stocking fillers for budding biotechnologists
}

Peter Finegold

\author{
Germ Zappers \\ By Fran Balkwill \& Mic Rolph \\ Cold Spring Harbor Laboratory Press; $\$ 8.95$, \\ 32pp, paperback \\ ISBN 0-87969-598-6, 2001 \\ Enjoy Your Cells \\ By Fran Balkwill \& Mic Rolph \\ Cold Spring Harbor Laboratory Press, \$8.95, \\ 32pp, paperback \\ ISBN 0-87969-584-6, 2001 \\ Baa! \\ By Cynthia Pratt Nicolson \& Rose Cowles \\ Kids Can Press; \$6.95, 40pp, paperback \\ ISBN 1-55074-886-6, 2001
}

If recent terrorist attacks generated anxiety in adults, then they likely terrified most children. For parents anxious to explain the "bio" in bio-terrorism, a book written by Professor Fran Balkwill and beautifully illustrated by Mic Rolph might provide some help—at least with the basics. Germ Zappers guides children of ages 7 and upwards through a voyage among psychedelic cyto-invaders. But what should be a whistle-stop tour gets distracted by a little too much sightseeing, with its attempts to explain defense and immune responses-a challenge even at graduate level. The coverage of microorganisms is sound, although the designation of bacteria as "friends" and viruses as "loathsome enemies" might encourage kids to use this as a justification to avoid washing-let's hope not.

The book is ambitious in its scope and will likely appeal only to the brightest of children, despite its attempt to demonstrate how to pronounce those difficult science words (e.g., "special chemicals called cytokines (sigh-toe-kines)"). I was left wondering whether the target age group (the 7's rather than the "upwards") really need to know the names of every lymphocyte. Can scientists such as Balkwill, who is also professor of cancer biology at St. Bartholomew's Hospital and Queen Mary's School of Medicine and Dentistry (London), remove themselves sufficiently from their specialism to write at this level? However, another of her books in the same series assuaged my concerns. Enjoy Your Cells is fun and fascinating. The phonetics are

Peter Finegold is a senior project manager in the Medicine in Society Program at The Wellcome Trust, London, UK (p.finegold@wellcome.ac.uk). less evident and the stories more convincing, although the author still insists on informing children about new-tro-

fils and mack-row-fages.

This is the sort of children's book that will encourage the reader to find out more.

"The most interesting book you'll ever read about genes and cloning" is how the third of the stocking fillers is billed. But Baa!, written by Cynthia Pratt Nicolson, finds it hard to live up to its extravagant boast. Baa! does explain genetics and cloning with clarity, using exciting real-

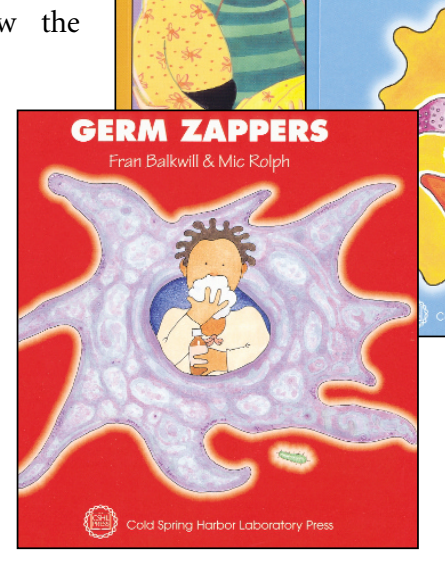

vampires, and the potential benefits and threats from widespread pre-implantation genetic testing are all used as examples. However, the illustrations-such an important component of a publication targeting ages 9-14-are dowdy. The characters also fail to reflect the diver-

life stories to bring the topic to life for young readers: the capture of the Unabomber, links between the genetic disorder porphyria and sity of the
human gene pool: basketball player Michael Jordan is cited as an example of how both genes and dedication can determine success, but other characters of color are conspicuously absent. And where are the women scientists? One other point of contention ... if the world's first cloned mice were produced in Hawaii, the first cloned calf in Texas, and Blacksburg, Virginia is the "cloned pig capital of the world", why no mention of Edinburgh, birthplace of Dolly the Sheep, the doyenne of clones, and presumably the impetus for the book's title?

\section{Agbiotech: history and mythology}

\section{Belinda Martineau}

Lords of the Harvest: Biotech, Big Money, and the Future of Food By Daniel Charles

Perseus Publishing; \$26.00, 368 pp, hardcover ISBN 0738202196, 2001

Lords of the Harvest documents the development and commercialization of genetically engineered crops. From before the first successful plant cell transformations in 1983 to the current public debate over so-called GM foods, Daniel Charles has painstakingly painted a big picture of the agricultural biotechnology industry. A daunting task, no doubt, but one that Charles, who had spent a decade cov-

Belinda Martineau is a former staff scientist at Calgene and the author of First Fruit: The Creation of the Flavr Savr Tomato and the Birth of Biotech Food (McGraw Hill, 2001). ering the topic as a technology correspondent with National Public Radio and Washington correspondent for New Scientist, was obviously up for. Taking advantage of his nonpartisan position as a journalist overlooking the biotech battle, Charles traveled "unimpeded between the bristling barricades" on either side of the "war over genetically engineered plants." As a result, his book is a refreshingly unbiased and thorough chronicle of the birth and formative years of the young agbiotech industry.

All the major scientific advances in molecular and cell biology that made the genetic engineering of plants possible are touched on in Lords of the Harvest. Brief histories of many of the world's most important crops-corn, soybeans, cotton, potatoes, and rice-and the seed and chemical industries that grew up around them, put the new technology in historical perspective. And Charles gives enough background on the biochemical nature, extensive 